\title{
Antimicrobial potential, phytochemical profile, cytotoxic and genotoxic screening of Sedum praealtum A. DC. (balsam)
}

Marcelo Fabiano Gomes Boriollo ${ }^{1 *}$, Milene Bueno Marques², Thaísla Andrielle da Silva', Jeferson Júnior da Silva ${ }^{1}$, Reigson Alves Dias ${ }^{3}$, Thyago Henrique Neves Silva Filho ${ }^{3}$, Isadora Letícia Ribeiro Melo ${ }^{3}$,

Carlos Tadeu dos Santos Dias ${ }^{4}$, Wagner Luís de Carvalho Bernardo ${ }^{1,5}$, Nelma de Mello Silva Oliveira²,

Vera Maria Peters ${ }^{6}$, José Francisco Höfling ${ }^{1}$ and Denise Madalena Palomari Spolidorio ${ }^{5}$

\begin{abstract}
Background: Sedum praealtum has been used for a long time in traditional medicine as an analgesic and antiinflammatory agent. Its beneficial effects have been known since ancient times, when Latinos used it to treat sore and swollen eyes. This research evaluated the antimicrobial potential, the cytotoxic and genotoxic effects, and some chromatographic profiles of the hydroethanolic extract of leaves, stems and roots of S. praealtum.

Methods: The antimicrobial activities were carried out by broth microdilution and agar diffusion. In vitro cytotoxicity was evaluated by cell cultures of Aedes albopictus and the selectivity index (SI) was estimated: $\mathrm{SI}=\mathrm{Cl}_{50} / \mathrm{MIC}$. Genotoxic and systemic toxic effects of S. praealtum leaves were analyzed by micronucleus assay in mice bone marrow. Chromatographic profiles and mass spectra were investigated by GC-MS.

Results: Gram-positive (B. subtilis, B. cereus, M. luteus, E. faecalis and S. aureus) and gram-negative (E. coli, E. aerogenes, S. marcescens, P. aeruginosa, P. mirabilis and S. typhimurium) bacteria exhibited MICs ranging from 12.5-50 and 0-50 mg/ $\mathrm{ml}$, respectively. Sedum praealtum showed no efficacy against $M$. tuberculosis and M. bovis. Cytotoxicity $\left(\mathrm{Cl}_{50}\right)$ of $\mathrm{S}$. praealtum was 4.22 and $5.96 \mathrm{mg} / \mathrm{ml}$ for leaves and stems, respectively, while its roots showed no cytotoxicity. Micronucleated polychromatic erythrocytes (MNPCEs) analyzes showed no differences between treatment doses $(0.5-2 \mathrm{~g} / \mathrm{kg})$ and negative control $(\mathrm{NaCl})$, but the PCE/NCE ratio (polychromatic erythrocyte/normochromatic erythrocyte) showed significant differences. Phytochemical screening identified thirteen compounds in the leaves, stems and roots of S. praealtum potentially associated with their biological activities.

(Continued on next page)
\end{abstract}

\footnotetext{
* Correspondence: marcelofgb@yahoo.com.br

'Laboratory of Microbiology and Immunology, Department of Oral Diagnosis, Dental School of Piracicaba, State University of Campinas (FOP/UNICAMP), Piracicaba, SP 13414-903, Brazil

Full list of author information is available at the end of the article
}

(c) The Author(s). 2020 Open Access This article is licensed under a Creative Commons Attribution 4.0 International License, which permits use, sharing, adaptation, distribution and reproduction in any medium or format, as long as you give appropriate credit to the original author(s) and the source, provide a link to the Creative Commons licence, and indicate if changes were made. The images or other third party material in this article are included in the article's Creative Commons licence, unless indicated otherwise in a credit line to the material. If material is not included in the article's Creative Commons licence and your intended use is not permitted by statutory regulation or exceeds the permitted use, you will need to obtain permission directly from the copyright holder. To view a copy of this licence, visit http://creativecommons.org/licenses/by/4.0/. The Creative Commons Public Domain Dedication waiver (http://creativecommons.org/publicdomain/zero/1.0/) applies to the data made available in this article, unless otherwise stated in a credit line to the data. 


\begin{abstract}
(Continued from previous page)
Conclusions: This research comprises a first scientific study on genotoxicity, cytotoxicity and antimicrobial effects of S. praealtum (Balsam), and it provides an initial theoretical foundation for its comprehensive use. Results showed antibacterial action of S. praealtum against gram-positive bacteria and some gram-negative species (depending on the plant anatomical part), but ineffective antimycobacterial action. However, S. praealtum leaves and stems display potential cytotoxicity, contributing to the $\mathrm{SI}<1$ values. In addition, S. praealtum leaves exhibit no clastogenic and/or aneugenic effects, but it has systemic toxicity dose-independent.
\end{abstract}

Keywords: Antimicrobial susceptibility, Cytotoxicity, Genotoxicity, Phytochemical screening, Sedum praealtum a. DC

\section{Background}

The genus Sedum (family Crassulaceae) features more than 350 species, which encompasses a large number of pharmacologically active species. Chemical studies of Sedum species have led to the isolation of several classes of substances, such as alkaloids, tannins, flavonoids and cyanogenic compounds [1-4]. The Sedum praealtum A. DC. species (synonym. Sedum dendroideum and Sedum dendroideum ssp. praealtum (A. DC.) [5-7] is a little bush with yellow flowers, found from Mexico to Guatemala, popularly known as Balsam [6]. According to classification, balm occupies the following taxonomic position: Division: Magnoliophyta; Class: Magnoliopsida; Subclass: Rosidae; Order: Rosales; Family: Crassulaceae; Genus: Sedum; Species: Sedum dendroideum subsp. praealtum (DC.) [8]. Balm is native to semidesert areas, 30 to $60 \mathrm{~cm}$ tall, fleshy, smooth, spatulated and recurved leaves gathered in whorls. Its inflorescences are terminal and branched, with numerous yellow flowers, formed in autumn and winter [9]. Its cultivation occurs singly or in groups, in full sun and fertile and permeable soil, as well as in rock gardens, being a drought- and frost-resistant plant. The juice of its leaves is said to be healing. The spread of Balsam (Sedum praealtum) is mainly due to the cutting of branches, which must be planted in $0.5 \times 0.5 \mathrm{~m}$ pits when plants have five to eight definite leaves [8].

Its beneficial effects have been known since ancient times, when Latinos used it to treat sore [10] and swollen eyes [11]. An aqueous decoction of S. praealtum parts has been used to ulcer treatments $[12,13]$, general inflammatory problems [14] and as contraceptive [15]. A preliminary study of the water extract of S. praealtum - however, under the name of $S$. dendroideum (Crassulaceae) showed an inhibitory effect on the motility of human sperm, as well as an anti-fertilization activity in SpragueDawley rats [16]. In another study, employing acetic acidinduced writhing (antinociceptive activity), croton oilinduced ear edema and carrageenan-induced peritonitis (anti-inflammatory activity) models in mice, it has been demonstrated that the main kaempferol glycosides can be responsible for the medicinal use of $S$. dendroideum against pain and inflammatory problems [13]. However, antimicrobial effects were reported only in two other species of the genus Sedum, S. aizoon, and S. tatarinowii [17]. The antimicrobial activity of medicinal plants has been attributed to small terpenoids and phenolics such as thymol, carvone, carvacrol, menthol and murolene, which also, in pure form, show antifungal or antibacterial activity. Although the mechanisms of action have been poorly characterized, this seems to be associated with the lipophilic nature of the compounds, with a buildup in membranes and loss of energy by the cells [18].

Biologically active compounds have been recognized for their pharmacological properties; however, several of these compounds could not be used in therapy because of their toxicological, carcinogenic, and mutagenic properties [19]. In the development of new drugs, analyses of genotoxicity assays represent a considerable weight, since most pharmaceutical industries deliberate the processing of new therapeutic agents also based on the data of in vitro and in vivo genotoxicity [20]. Thus, the assays for evaluation of mutagenic activity of plants used by the population as well as their isolated substances are essential to establish control measures on indiscriminate use. In addition, it is necessary to clarify the mechanisms and conditions that decided the biological effect, before the plants are viewed as therapeutic agents [21]. The in vivo micronucleus $(\mathrm{MN})$ assay in mice bone marrow plays a crucial role in tests that aim to identify risks for mutagen agents [22], especially the evaluation of mutagenic risks that allows the consideration of in vivo metabolic factors, pharmacokinetics, and DNA repair processes although these may vary among species, tissues and genetic mechanisms [23]. In addition, the knowledge of genotoxic effects induced by herbal medicines and foods using the $\mathrm{MN}$ in vivo assay in mammals has been the aim of several research groups [24-27].

Although little information about the popular knowledge and the scientific research support the potential therapeutic effectiveness of the aqueous decoction, aqueous extract or lyophilization of balsam juice (S. praealtum), as ocular symptoms [10, 11], gastric ulcer [12, 13], anti-inflammatory action [14], contraceptive [15], inhibition of human sperm motility and anti-fertilization activity in mice [16], a limited and/or non-existent number of investigations aimed to examine the antimicrobial - 
only the Sedum aizoon and Sedum tatarinowii species [17] - and genotoxic effects has been observed so far. Aiming to contribute with information about the antimicrobial and genotoxic potential of herbal medicine, particularly of the hydroethanolic extract of the stem, leaf, and root of S. praealtum (Balsam), we evaluated ( $i$ ) in vitro antibacterial, antimycobacterial and antifungal action employing broth microdilution and the agar diffusion test and (ii) the in vitro cytotoxic activity using cellular culture of Aedes albopictus. We also analyzed the genotoxic effects of $S$. praealtum leaves through the in vivo micronucleus assay in mice bone marrow.

\section{Methods}

\section{Plant extract}

The whole plant of S. praealtum (stem, leaf and root) was collected from the urban area of the Alfenas city, Minas Gerais State, Brazil (21 $24^{\prime} 44.98^{\prime \prime} \mathrm{S}$ and $45^{\circ}$ 57' 39.87" W, elevation of $818 \mathrm{~m}$ ). This plant has been kindly identified by a plant taxonomist (Federal University of Alfenas - UNIFAL-MG) and filed in the Rede Nacional de Herbários da Sociedade Botânica do Brasil (UNIFAL-MG UALF), voucher specimen no. 1024. Anatomical parts of the plant (stem, leaf and root) were cleaned and manually cut and hydroalcoholic extracts have been macerated $(200 \mathrm{mg} / \mathrm{ml})$ for 7 days in ethanol $70 \mathrm{GL}$, in the dark and under daily stirring. Then, these extracts were subjected to the filtering process using nylon and paper filters.

Prior to antimicrobial susceptibility testing, cytotoxicity and genotoxicity assays, aliquots $(500 \mathrm{ml})$ of these extracts were submitted to solvent removal proceedings by rotary evaporation $(40 \mathrm{rpm})$ (Rotary Evaporator RV 10 Control V, IKA ${ }^{\circ}$ Works, Inc., USA) coupled in bath heating systems $\left(40^{\circ} \mathrm{C}\right.$ ) (Heating Baths HB10, IKA ${ }^{\circ}$ Works, Inc., USA), vacuum pump (175 mbar) (Chemistry diaphragm pump MD 1C, VACUUBRAND GMBH + CO KG, Wertheim, Germany), recirculator of distilled water $\left(10^{\circ} \mathrm{C}\right)$ (Banho Ultratermostatizado Microprocessado Digital, SPLABOR, cod. \# SP-152/10, Presidente Prudente, SP, Brazil) and evaporation bottle (RV 10.85 Evaporation Flask, NS 29/32-2 L, IKA ${ }^{\circ}$ Works, Inc., USA). The final product was transferred to $1 \mathrm{~L}$ reaction bottle $\left(\mathrm{SCHOTT}^{\circ} \mathrm{DURAN}^{\circ}\right.$ ) and kept at $-20^{\circ} \mathrm{C}$ for 24 $\mathrm{h}$, to evaluate the freezing of the final product and the efficacy of the solvent evaporation process [27]. Then, aliquots $(15 \mathrm{ml})$ of this final product were transferred to penicillin glass vials $(50 \mathrm{ml})$ and lyophilized $(0.12 \mathrm{mbar}$ at $-50^{\circ} \mathrm{C}$ ) (Lyophilizer model Alpha 1-2 LDPlus, Martin Christ Gefrier trocknung sanlagen $\mathrm{GmbH} \odot$, Germany) and their dry mass was measured (Electronic Analytical Balance AUW-220D, Shimadzu Corp., Kyoto, Japan). The lyophilized final product (stem, leaf and root of $S$. praealtum) was prepared in aqueous solvent (Type
1 water, Sistema Milli-Q Direct 8, Millipore Indústria e Comércio Ltda., Barueri, SP, Brazil) at concentrations of $20 \times$ (in vitro antimicrobial susceptibility testing) and $2 \times$ (in vitro cytotoxicity and in vivo genotoxicity assays), sterilized by filtration (Millipore Corporation, hydrophilic Durapore PVDF, $0.22 \mu \mathrm{m}, \varnothing 47 \mathrm{~mm}$, cat. \# GVWP 047 00), and stored in sterile polypropylene tubes $(50 \mathrm{ml})$ at $-70^{\circ} \mathrm{C}$ until use.

\section{Qualitative analysis by gas chromatography - mass spectrometry (GC-MS)}

The lyophilized final product (stem, leaf and root of $S$. praealtum) was partially dissolved with ethanol. The dispersions were filtered and analyzed by GC-MS (Aligent 5975C TAD Series GC/MSD System,@Aligent Technologies, Inc., CA, USA) using the following chromatographic conditions: (i) Sample: injected volume of $2.0 \mu \mathrm{l}$; (ii) Column: HP-5MS, 5\% diphenyl, 95\% dimethylpolysiloxane $(30 \mathrm{~m} \times 0.25 \mathrm{~mm} \times 0.25 \mu \mathrm{m}) ;$ (iii) Drag gas: $\mathrm{He}$ (99.9999) $\rightarrow 1 \mathrm{ml} / \mathrm{min}$; (iv) Injector: $280^{\circ} \mathrm{C}$, Split 1:10 (leaf and root) and 1:1 (stem); (v) Oven: $50^{\circ} \mathrm{C}(2 \mathrm{~min}) \rightarrow 250^{\circ} \mathrm{C}$ $\left(5{ }^{\circ} \mathrm{C} / 1 \mathrm{~min}\right) ; 250^{\circ} \mathrm{C}(10 \mathrm{~min})$; and (vi) Detector: Linear quadrupole mass spectrometer, Ionization source (impact by electrons $\rightarrow 70 \mathrm{eV})$, Scan mode $(0.5 \mathrm{~s} / \mathrm{scan})$, Mass range $[33-500 \mathrm{Da}(\mathrm{u})]$, Line transfer $\left(280^{\circ} \mathrm{C}\right)$ and Filament (off at $7.0 \mathrm{~min}$ ). The Mass Spectral Database (NIST 11) was used to identify compounds detected in the chromatograms [28].

\section{Microbial strains}

A total of 11 bacterial strains (Bacillus subtilis ATCC $^{\circ}$ 6633, Bacillus cereus ATCC ${ }^{\bullet} 11778$, Micrococcus luteus ATCC 9341, Enterococcus faecalis ATCC ${ }^{\bullet}$ 51299, Staphylococcus aureus ATCC ${ }^{\circ}$ 6538, Escherichia coli ATCC $^{\ominus}$ 25922, Serratia marcescens LMI-UNIFAL, Pseudomonas aeruginosa ATCC 27853 , Proteus mirabilis ATCC 25922, Salmonella typhimurium ATCC ${ }^{\bullet}$ 14028 and Enterobacter cloacae LMI-UNIFAL), 2 strains of yeasts (Candida albicans ATCC 10231 and Saccharomyces cerevisiae ATCC 2601) and 2 mycobacterial strains (Mycobacterium tuberculosis ATCC ${ }^{\ominus} 25177$ [H37Ra] and Mycobacterium bovis [BCG]), belonging to the bacteria collection of the Laboratory of Pharmacogenetics and Molecular Biology, University of Alfenas (UNIFENAS), were subjected to susceptibility tests against lyophilized extracts of S. praealtum.

\section{Agar diffusion method (bacteria and yeasts)}

The profile of the in vitro antimicrobial susceptibility of bacterial and yeast strains against $S$. praealtum extracts was determined by the agar diffusion method, following the guidelines established by the Clinical and Laboratory Standards Institute [29-31], with some adaptations [32]. Prior to testing, bacteria and yeasts were grown in $\mathrm{BHI}$ 
agar at $35^{\circ} \mathrm{C}$ for $24 \mathrm{~h}$ and in SDA agar at $35^{\circ} \mathrm{C}$ for $24 \mathrm{~h}$, respectively. Then, a 10- $\mu$ loop inoculum of each microbial sample was resuspended in $5 \mathrm{ml}$ of sterile saline solution $(145 \mathrm{mM} \mathrm{NaCl})$ and set to a turbidity of 0.5 on the McFarland scale (bacteria: $1-4 \times 10^{8} \mathrm{CFU} / \mathrm{ml}$; yeasts: $1-5 \times 10^{6} \mathrm{CFU} / \mathrm{ml}$ ) or equivalent to a transmittance of 79.5-83.2\% using spectrophotometer (Thermo Scientific Multiskan GO UV/Vis, Microplate and Cuvette Spectrophotometer, ref. \# 51119200, Thermo Fisher Scientific Inc., Waltham, MA, USA) with $625 \mathrm{~nm}$ wavelength (bacteria) and $530 \mathrm{~nm}$ (yeasts) $(\mathrm{T}=79.5-83.2 \% \rightarrow \mathrm{A} 625$ $\mathrm{nm} / 530 \mathrm{~nm}=2-\log _{10} \% \mathrm{~T} \rightarrow$ A $625 \mathrm{~nm} / 530 \mathrm{~nm}=0.100-$ 0.080 ). This cell suspension was vortex-stirred for $15 \mathrm{~s}$ and plated (Spread-Plate method) on sterile $\mathrm{MH}$ agar medium, 7.2 to $7.4 \mathrm{pH}$ (Mueller Hinton no. 2 Control Cations, code \# M1657, Himedia), and on sterile MH agar medium supplemented with $2 \%$ glucose for bacteria and yeasts, respectively, previously prepared in Petri dish $(150 \times 15 \mathrm{~mm} ; 50 \mathrm{ml}$ growth medium/plate; height in each plate equal to $4 \pm 0.5 \mathrm{~mm}$ ). These plates were kept at room temperature for $15 \mathrm{~min}$ to complete absorption of the inoculum into the culture medium. Then, $40 \mu \mathrm{l}$ of each extract $(100 \mathrm{mg} / \mathrm{ml})$ were poured in wells $(4 \mathrm{~mm})$ evenly made on the surface of the inoculated culture medium, and the plates were inversely incubated at $35^{\circ} \mathrm{C}$ for $24 \mathrm{~h}$. These tests were performed in triplicate assay systems and the interpretation of results was carried out from the zone of inhibition of microbial growth ( $\varnothing$ of the halo in $\mathrm{mm})$. Chlorhexidine to $0.12 \%(\mathrm{~m} / \mathrm{v})$ and Type 1 water were used as positive control (zone of inhibition) and negative (lack of zone of inhibition), respectively.

\section{Microdilution method}

The minimum inhibitory concentration (MIC) of $S$. praealtum extracts against bacterial and yeast strains was determined by the broth microdilution method, following the guidelines established by the Clinical and Laboratory Standards Institute [33-35], with some adaptations [32]. The concentrations tested covered a range of $50,25,12.5,6.25,3.125,1.562,0.781,0.390$, $0.195,0,097,0.048$ and $0.024 \mathrm{mg} / \mathrm{ml}$. These tests were performed in triplicate assay systems employing microdilution plates with multiple wells (96-well cell culture microplates, flat-bottom, Corning Inc., NY, USA), containing $50 \mu \mathrm{l}$ of sterile $\mathrm{MH}$ agar medium, 7.2 to $7.4 \mathrm{pH}$ for bacteria, and sterile $\mathrm{MH}$ agar medium supplemented with $2 \%$ glucose for yeasts, in ultrapure Type 1 water.

Prior to the tests:

(i) standard solutions of lyophilized extracts (concentrations of 20x) were diluted in $\mathrm{MH}$ liquid culture medium. Thus, $50 \mu \mathrm{l}$ aliquots of these dilutions were applied to the first wells of each row of the microdilution plates containing $\mathrm{MH}$ liquid culture medium $(50 \mu \mathrm{l})$, according to the procedures of serial dilutions $(2 \times)$, to create different concentrations of the extracts to be tested;

(ii) bacteria and yeasts were grown in BHI and SDA agar, respectively, at $35^{\circ} \mathrm{C}$ for $24 \mathrm{~h}$. Then, a 10- $\mu \mathrm{l}$ loop inoculum of each microbial sample was resuspended in $5 \mathrm{ml}$ of sterile saline solution $(145 \mathrm{mM} \mathrm{NaCl})$ and set to a turbidity of 0.5 on the McFarland scale (bacteria: $1 \times 10^{8} \mathrm{CFU} / \mathrm{ml}$; yeasts: $1-5 \times 10^{6} \mathrm{CFU} / \mathrm{ml}$ ) or equivalent to a transmittance of $79.5-83.2 \%$ using a spectrophotometer with a wavelength of $625 \mathrm{~nm}$ (bacteria) and $530 \mathrm{~nm}$ (yeasts) $\left(\mathrm{T}=79.5-83.2 \% \rightarrow \mathrm{A}_{625 \mathrm{~nm} / 530 \mathrm{~nm}}=2-\right.$

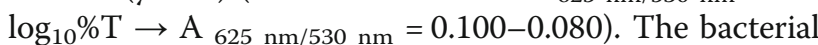
cell suspension was vortex-stirred for $15 \mathrm{~s}$ and diluted in a 1:10 proportion in sterile saline solution $\left(1 \times 10^{7} \mathrm{CFU} /\right.$ $\mathrm{ml})$. In turn, the yeast cell suspension was vortex-stirred for $15 \mathrm{~s}$ and diluted in a 1:10 proportion in sterile saline solution $\left(1-5 \times 10^{5} \mathrm{CFU} / \mathrm{ml}\right)$, followed by a new 1:10 dilution $\left(1-5 \times 10^{4} \mathrm{CFU} / \mathrm{ml}\right)$. During the assays, aliquots of $5 \mu \mathrm{l}$ of each working inoculum (5\% of well volume) were placed in the microdilution wells, containing $100 \mu \mathrm{l} /$ well of $\mathrm{MH}$ liquid culture medium and different concentrations of the products to be tested (S. praealtum): final concentration of the bacterial inoculum equal to $5 \times 10^{5} \mathrm{CFU} / \mathrm{ml}$ and yeast inoculum equal to 0.5 $2.5 \times 10^{3} \mathrm{CFU} / \mathrm{ml}$.

Afterwards, these microdilution plates were incubated at $35^{\circ} \mathrm{C}$ for $24 \mathrm{~h}$ (bacteria) and $48 \mathrm{~h}$ (yeasts). Soon after the incubation period, $30 \mu \mathrm{l}$ aliquots of resazurin solution (Resazurin sodium salt, Cat. \#R7017, Sigma-Aldrich Co., St. Louis, MO., USA), previously prepared in $0.02 \%(\mathrm{~m} / \mathrm{v})$ in Type 1 water, sterilized by filtration and stocked at $4{ }^{\circ} \mathrm{C}$ for up to 1 week, were added to each well and the plates were reincubated overnight. Interpretation of results was made through visual reading of test plates. A change in color from blue to pink indicated microbial growth. MIC was defined as the lowest concentration of drug that prevented this color change [36].

\section{Minimum microbicidal concentration (MMC).}

The minimum microbicide concentration (MMC) was determined according to the modifications previously proposed [37]. For each microbial strain, $50 \mu \mathrm{l}$ aliquots of the total volume of the well corresponding to the MIC were homogenized with a pipette and grown in Petri dishes $(90 \times 15 \mathrm{~mm})$ containing $\mathrm{BHI}$ and SDA agar to bacteria and yeasts, respectively. Each aliquot was placed gently at a given point on the growing medium and kept at room temperature for complete absorption. Therefore, the plate was streaked to separate microorganisms and remove them from drug sources (S. praealtum extracts) [38], and incubated at $35^{\circ} \mathrm{C}$ for $46-48 \mathrm{~h}$. MMC was the lowest concentration of the drug (extract) able to eliminate $\geq 99.9 \%$ of the final inoculum (0.05- 
0.25 colony), whereas microstatic activity was defined from the reduction of $\leq 99.9 \%$ of the final inoculum [37].

\section{Agar diffusion method (mycobacteria)}

The profile of the antimicrobial susceptibility against $S$. praealtum extracts was determined by the agar diffusion method, following the guidelines established by the Clinical and Laboratory Standards Institute [39]. M. tuberculosis ATCC 25,177 (H37Ra) and M. bovis (BCG) strains were tested on Middlebrook 7H10 agar (Middlebrook 7H10 AgarBD, Cat. \#295964, Becton, Dickinson and Company, New Jersey, USA), with Middlebrook OADC Enrichment added (BBL Middlebrook OADC Enrichment, Cat. \#212240, Becton, Dickinson and Company, New Jersey, USA). Prior to testing, filter paper discs (10 $\mathrm{mm} \varnothing)$ were moistened with solutions of extracts (50 $\mathrm{mg} / \mathrm{ml}$ ) and oven-dried at $37^{\circ} \mathrm{C}$. Discs containing $0.12 \%$ $\mathrm{m} / \mathrm{v}$ chlorhexidine and Type 1 water were used as positive control (zone of inhibition) and negative (lack of zone of inhibition), respectively. Freshly cultivated mycobacterial cells were resuspended in $5 \mathrm{ml}$ of sterile saline solution (145 mM NaCl), adjusted to a turbidity of 0.5 on the McFarland scale, with the aid of glass beads for breakdown of the colonies, and poured (Spread-Plate method) on the agar. Agars were kept at room temperature for $15 \mathrm{~min}$ to complete absorption of the inoculum. Afterwards, discs containing S. praealtum extracts were dispensed on the surface of the inoculated culture medium, and the plates were inversely incubated at $35^{\circ} \mathrm{C}$ for 8 weeks (i.e., cultures were analyzed within 5-7 days after inoculation and once a week thereafter, until 8 weeks). These tests were performed in triplicate assay systems and the interpretation of results was carried out from the zone of inhibition of microbial growth ( $\varnothing$ of the halo in $\mathrm{mm}$ ). For satisfactory susceptibility results (i.e., presence of growth inhibition zone), the determination of MIC against S. praealtum extracts can be performed following the guidelines established by the Clinical and Laboratory Standards Institute [39].

\section{In vitro cytotoxicity assay}

In vitro cytotoxicity $(\mathrm{CI})$ of $S$. praealtum extracts was determined by the MTT method (Methylthiazolyldiphenyl-tetrazolium bromide), as previously described [32] Cells (derived from Aedes albopictus mosquito larvae) were poured $\left(1 \times 10^{4}\right.$ cells per well $)$ in microdilution plates with multiple wells (96-well), containing $100 \mu \mathrm{l}$ of L-15 medium (L-15 Medium [Leibovitz], without Lglutamine, liquid, sterile-filtered, suitable for cell culture. Cat. \#L5520, Sigma-Aldrich Co., St. Louis, MO., USA), supplemented with $1 \%$ fetal bovine serum (Fetal Bovine Serum, USA origin, sterile-filtered, suitable for cell culture. Cat. \#F6178, Sigma-Aldrich Co., St. Louis, MO., USA). Then, microdilution plates were incubated at $37^{\circ} \mathrm{C}$ for $72 \mathrm{~h}$ under a atmosphere of $5 \% \mathrm{CO}_{2}$. Shortly after the incubation period, $100 \mu \mathrm{l}$ aliquots of L-15, added with decreased dilutions of $S$. praealtum extracts $(0.039$ to $5 \mathrm{mg} / \mathrm{ml})$ were dispensed into the wells of the microdilution plates, which were incubated at room temperature for $48 \mathrm{~h}$. As cellular growth control of $\mathrm{Ae}$ des albopictus, we used only the culture medium L-15 added with bovine fetal serum. After the reincubation period, aliquots of $10 \mu \mathrm{l}$ of MTT solution $(5 \mathrm{mg} / \mathrm{ml})$ (Thiazolyl Blue Tetrazolium Bromide, powder, BioReagent, suitable for cell culture, suitable for insect cell culture, $\geq 97.5 \%$ [HPLC]. Cat. \#M5655, Sigma-Aldrich Co., St. Louis, MO., USA) were added to the wells of the microdilution plates and incubated for $4 \mathrm{~h}$ at room temperature, to incorporate the MTT cell and create formazan crystals. The reading of results was done by spectrophotometric analysis with wavelength of $600 \mathrm{~nm}$ $\left(\mathrm{A}_{600 \mathrm{~nm}}\right)$. The percentage of in vitro cytotoxicity $\left(\mathrm{CI}_{\%}\right)$ was calculated using the following formula: $A \times B /$ $A \times 100$, where $A$ and $B$ correspond to the values of $\mathrm{A}_{600 \mathrm{~nm}}$ obtained from the control of cell growth (L-15 medium + bovine fetal serum + Aedes albopictus) and cell growth in the presence of $S$. praealtum (L-15 medium + bovine fetal serum + Aedes albopictus + dilutions of extracts), respectively. In vitro cytotoxicity (CI) of $50 \%\left(\mathrm{CI}_{50}\right)$ and $90 \%\left(\mathrm{Cl}_{90}\right)$ were estimated using linear regression and defined as the extract concentrations capable of reducing 50 and $90 \%$, respectively, of the $A_{600} \mathrm{~nm}$ values obtained from cell growth in the presence of $S$. praealtum in comparison with those of the control of cell growth. All these tests were performed in duplicate assay system with control of cell viability.

\section{In vivo micronucleus assay}

Healthy, heterogeneous, young adult male and female Swiss albinus (Unib: SW) mice (between 7 and 12 weeks pubescent period), with a body weight between $30 \mathrm{~g}$ and $40 \mathrm{~g}$ (i.e., the variation weight between the animals, for each sex, should not exceed $\pm 20 \%$ of medium mass) were provided by CEMIB (Multidisciplinary Center for Biological Investigation on Laboratory Animal Science UNICAMP), and erythrocytes from the bone marrow of these mice were used in the micronucleus assay. Animals were kept in same-sex groups, in polypropylene boxes, in an air-conditioned environment of $22 \pm 3{ }^{\circ} \mathrm{C}$, with relative humidity of $50-60 \pm 10 \%$, and 12-h day-night cycles (i.e., $12 \mathrm{~h}$ light and $12 \mathrm{~h}$ dark). Mice were fed with Purina ${ }^{\circ}$ Labina commercial rations (Nestlé Purina Pet Care Company) and water ad libitum. In addition, they were acclimated to laboratory conditions for 7 days (trial period) before the experiment. At the end of the trial period, each animal was weighed and, according to weight, received 1 $\mathrm{ml} / 100 \mathrm{~g}$ body weight of the indicated liquid (negative control, positive control and herbal medicine). After the 
experimental treatment, animals were euthanized by $\mathrm{CO}_{2}$ asphyxiation in adapted acrylic chambers [23, 27]. This research was approved by the Ethics Committee in Research Involving Animals of UNIFENAS (CEPEAU Protocol No. 08A/2014).

Groups of animals (consisting of 5 males and 5 females each) were treated using a single dosing regimen administered by gavage (herbal medicine and negative control) or intraperitoneally (positive control) and two euthanasia times ( 24 and $48 \mathrm{~h}$ ), based on the regulatory recommendation regarding the in vivo micronucleus assay: (i) Control groups: $150 \mathrm{mM} \mathrm{NaCl}$ (negative control), $50 \mathrm{mg} / \mathrm{kg}$ of $\mathrm{N}$ Nitroso-N-ethylurea (positive control: NEU, Sigma N8509, CAS No. 759-73-9); (ii) Genotoxicity test (herbal medicines): 500, 1000 and $2000 \mathrm{mg} / \mathrm{kg}$ of lyophilized extracts of $S$. praealtum leaves diluted in Type 1 water. The maximum tolerated dose (MTD) was defined as the highest dose that can be administered without inducing lethality or excessive toxicity during the study, causing moribund euthanasia, or a dose that produces some indication of toxicity of the bone marrow (e.g. a reduction in the proportion of immature erythrocytes among total erythrocytes in the bone marrow), or $2000 \mathrm{mg} / \mathrm{kg}[23,27]$.

Shortly after euthanasia, the femora were surgically and aseptically removed, and the animals were appropriately discarded. Each femur was sectioned at the proximal end and the contents of the spinal canal were washed with $1.5 \mathrm{ml}$ of a $150 \mathrm{mM} \mathrm{NaCl}$ solution and then transferred to a $15 \mathrm{ml}$ centrifuge tube. This material was resuspended with a Pasteur pipette to ensure a random distribution of bone marrow cells. The suspension was then centrifuged at $1000 \mathrm{rpm}$ (Centrifuga de Bancada Microprocessada, Mod. NT 810, Nova Técnica Ind. e Com. de Equip. para Laboratório Ltda., Piracicaba, SP, Brasil) for $5 \mathrm{~min}$. The supernatant was discarded and the resulting sediment was resuspended in $500 \mu \mathrm{l}$ of a 150 $\mathrm{mM} \mathrm{NaCl}$ solution enhanced with $4 \%$ formaldehyde. Slides were smeared ( 2 slides per animal), then dried at room temperature for $24 \mathrm{~h}$ and stained with Leishman's eosin methylene blue dye (pure dye for $3 \mathrm{~min}$, followed by diluted dye in Type 1 water in a 1:6 proportion for $15 \mathrm{~min}$ ) to tell apart polychromatic erythrocyte (PCE) from normochromatic erythrocyte (NCE) [23, 27].

Polychromatic erythrocytes (PCEs) were observed at a magnification of 1000× using optical microscopy (Nikon Eclipse E-200), counted (at least 4000 enucleated polychromatic erythrocytes were scored per animal for the incidence of micronucleated polychromatic erythrocytes) with the aid of a digital cell counter (Contador Diferencial CCS02, Kacil Indústria e Comércio Ltda., PE, Brasil) and photographed using an 8.1 Megapixel Digital Camera (DC FWL 150). The number of PCEs and NCEs and the number and frequency of micronucleated polychromatic erythrocytes (MNPCEs) were reported. To evaluate bone marrow toxicity, the ratio of PCE to NCE was also observed. This PCE:NCE ratio indicates the acceleration or inhibition of erythropoiesis and it has been reported to vary with scoring time. A continuous decline in the PCE:NCE ratio may be due to the inhibition of cell division, the killing of erythroblasts, the removal of damaged cells, or dilution of the existing cell pool with newly-formed cells $[23,27]$.

\section{Data analysis}

Data obtained in the extract disk diffusion testing were submitted to analysis of one-way variance (ANOVA) and medium comparison with Scott-Knott's test $(\alpha=0.05)$. $\mathrm{IC}_{50}$ and MIC data were used to calculate the selectivity index (SI) of each extract ( $\left.\mathrm{SI}=\mathrm{IC}_{50} / \mathrm{MIC}\right)$, as previously reported [40]. Data obtained in the micronucleus assay were submitted to ANOVA using a factorial scheme of $5 \times 2 \times 2$ (treatment $\times$ sex $\times$ euthanasia time), and medium comparison with Tukey's test $(\alpha=0.05)$ using the $\mathrm{SAS}^{\bullet}$ version 9.3 computer software [27].

\section{Results \\ Qualitative analysis by GC-MS}

Chromatographic profiles and mass spectra of lyophilized extracts (stem, leaf and root of S. praealtum) were summarized in Table 1 and Fig. 1

\section{In vitro antimicrobial susceptibility testing and cytotoxicity assay}

The in vitro antimicrobial susceptibility profile of gramnegative bacterial strains (E. coli, E. aerogenes, S. marcescens, $P$. aeruginosa, $P$. mirabilis and $S$. typhimurium) against lyophilized extracts of the stem, leaf and root of S. praealtum, as determined by the agar diffusion method, showed absence of inhibition zones of microbial growth $\left(\varnothing_{\mathrm{mm}}\right.$ of the halo equivalent to 0$)$. Considering the gram-positive bacterial strains, the presence of the inhibition zone of microbial growth $\left(\varnothing_{\mathrm{mm}}\right.$ of halo) was observed for a greater number of the analyzed strains against the hydroalcoholic extract of the root of $S$. praealtum (4 out of 5 strains: B. subtilis, B. cereus, $M$. luteus and $S$. aureus), followed by the stem (3 out of 5 : B. cereus, M. luteus and S. aureus) and the leaf (2 out of 5: B. cereus and $M$. luteus). However, significant statistical differences $(p<0.05)$ were observed only on the inhibition zones of microbial growth $\left(\varnothing_{\mathrm{mm}}\right.$ of halo) formed from the M. luteus species and the lyophilized extract of the $S$. praealtum stem. Among the analyzed yeast strains (C. albicans and $S$. cerevisiae), only for the $S$. cerevisiae species there were growth inhibition zones against the lyophilized extracts of $S$. praealtum stems and roots. Hydroalcoholic extracts of S. praealtum stem, leaf and root did not show any growth inhibition zones against M. tuberculosis and M. bovis strains. All positive 
Table 1 Phytochemical screening (qualitative analysis) of the lyophilized extracts of S. praealtum (stem, leaf and root) by GCMS.

\begin{tabular}{lclll}
\hline Peak & $\mathrm{t}_{\mathrm{R}}$ & Compound name & \%A & Quality \\
\hline Leaf of S. praealtum & & & \\
1 & 34.014 & Phytol & 60.92 & 91 \\
2 & 41.174 & Propyl pentil phthalate & 30.08 & 91 \\
Stem of S. praealtum & & & \\
1 & 31.218 & Hexadecanoic acid & 5.56 & 99 \\
2 & 31.852 & Ethyl hexadecanoate & 10.88 & 96 \\
3 & 34.017 & Phytol & 5.06 & 91 \\
4 & 34.371 & Octadecadienoic acid & 2.39 & 98 \\
5 & 34.485 & Hexadecatrienal & 2.95 & 72 \\
6 & 34.901 & Ethyl linoleate & 18.41 & 99 \\
7 & 35.016 & Ethyl octadecatrienoate & 16.81 & 99 \\
8 & 40.552 & Monopalmitin & 4.73 & 91 \\
9 & 41.186 & Di octyl phthalate & 8.62 & 91 \\
10 & 50.468 & Sitosterol & 24.60 & 99 \\
Root of S. praealtum & & & \\
1 & 29.394 & Isobutyl undecyl phthalate & 11.54 & 74 \\
2 & 31.236 & Not determined & 8.84 & - \\
3 & 31.850 & Not determined & 6.07 & - \\
4 & 34.889 & Not determined & 7.81 & - \\
5 & 41.184 & Di isoctil phthalate & 65.74 & 91 \\
\hline
\end{tabular}

$\mathrm{t}_{\mathrm{R}}$ : retention time (minutes). \%A: percentage of normalized area. Quality indexes $>70$ were adopted controls (chlorhexidine for bacteria and yeasts; rifamycin to mycobacteria) produced significantly different $(p<0.05)$ growth inhibition zones from those observed in lyophilized extracts of $S$. praealtum stem, leaf and root (Table 2).

Although without any zone of inhibition of gramnegative bacterial growth, the minimum inhibitory concentration (MIC) revealed (i) MIC values equal to 25 $\mathrm{mg} / \mathrm{ml}$ in five species (E. coli, S. marcescens, $P$. aeruginosa, P. mirabilis and S. typhimurium) and $50 \mathrm{mg} / \mathrm{ml}$ in one species ( $E$. aerogenes) using the lyophilized extract of $S$. praealtum leaves, (ii) MIC value equal to $25 \mathrm{mg} / \mathrm{ml}$ in one species (E. coli) using the $S$. praealtum stem extract, and (iii) MIC value equal to $50 \mathrm{mg} / \mathrm{ml}$ in one species ( $P$. mirabilis) using the $S$. praealtum root extract. For gram-positive bacteria, MIC values were $(i)$ equal to $12.5 \mathrm{mg} / \mathrm{ml}$ (M. luteus), $25 \mathrm{mg} / \mathrm{ml}$ (B. cereus, E. faecalis and $S$. aureus) and $50 \mathrm{mg} / \mathrm{ml}$ (B. subtilis) using the lyophilized extract of $S$. praealtum leaves, (ii) equal to 25 $\mathrm{mg} / \mathrm{ml}$ (B. cereus, M. luteus, E. faecalis and S. aureus) and $50 \mathrm{mg} / \mathrm{ml}$ (B. subtilis) using the extract of S. praealtum stems, (iii) and equal to $12.5 \mathrm{mg} / \mathrm{ml}$ (B. cereus, $M$. luteus, E. faecalis and S. aureus) and $25 \mathrm{mg} / \mathrm{ml}$ (B. subtilis) using $S$. praealtum root extracts. Among yeast strains, S. cerevisiae showed MIC values equal to 6.25 $\mathrm{mg} / \mathrm{ml}, 12.5 \mathrm{mg} / \mathrm{ml}$ and $6.25 \mathrm{mg} / \mathrm{ml}$ using lyophilized extracts of S. praealtum leaves, stems and roots, respectively. C. albicans showed susceptibility only against the S. praealtum roots (MIC equal to $25 \mathrm{mg} / \mathrm{ml}$ ) (Table 2).

Microbicide activities $(25-50 \mathrm{mg} / \mathrm{ml})$ of lyophilized extracts of $S$. praealtum were observed only in two species of gram-negative bacteria (S. marcescens: leaf; and $P$. mirabilis: root), three species of gram-positive bacteria (B. subtilis: root; M. luteus: leaf, stem and root; and S. aureus: leaf and root) and in the S. cerevisiae yeast (leaf, stem and root) (Table 2).
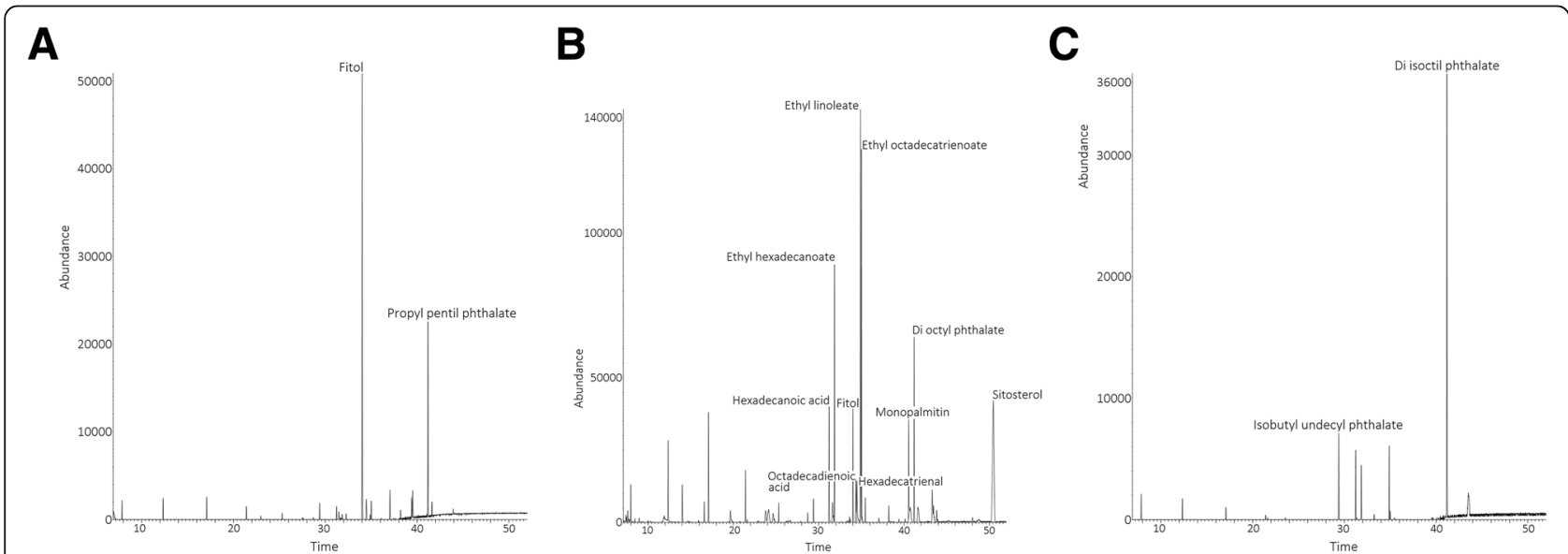

Fig. 1 Chromatographic profiles of the lyophilized extracts of leaf (A), stem (B) and root (C) of S. praealtum using gas chromatography - mass spectrometry (GC-MS) and mass spectral database (NIST 11) 
Table 2 Minimum inhibitory concentration (MIC), minimum microbicidal concentration (MMC), mean values of inhibition halos $\left(M \varnothing_{\mathrm{h}} \mathrm{mm}\right)$ and selectivity index (SI) obtained from in vitro antimicrobial susceptibility testing and cytotoxicity assays of the lyophilized extracts of S. praealtum

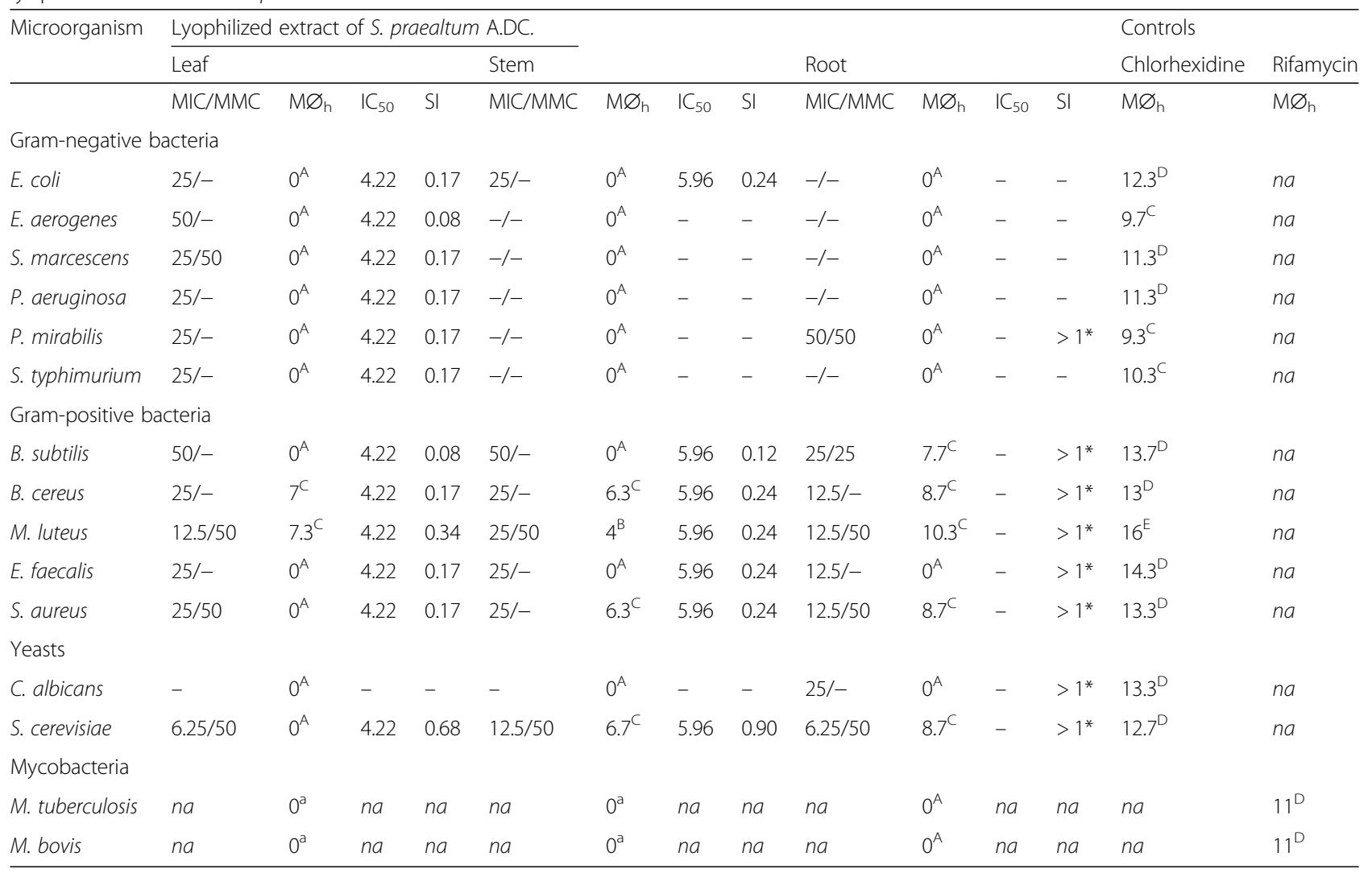

For all gram-negative and gram-positive bacterial species that had a MIC between 12.5 and $50 \mathrm{mg} / \mathrm{ml}$ against lyophilized extracts of $S$. praealtum leaves and stems, the SI was $<1.0(0.08-0.34)$. A SI $<1(0.68-0.90)$ was also observed in the $S$. cerevisiae specie for the lyophilized extracts of S. praealtum leaves (MIC equal to 6.25 $\mathrm{mg} / \mathrm{ml}$ ) and stems (MIC equal to $12.5 \mathrm{mg} / \mathrm{ml}$ ). Since the lyophilized extract of the $S$. praealtum root showed no in vitro cytotoxicity $(\mathrm{CI})$ under tested conditions, the SI of the root extract was considered $>1$ against MICs of $P$. mirabilis, B. subtilis, B. cereus, M. luteus, E. faecalis, S. aureus, C. albicans and S. cerevisiae (Table 2). These SI were obtained from the results of the percentage of in vitro cytotoxicity $\left(\mathrm{CI}_{50}\right.$ and $\left.\mathrm{CI}_{90}\right)$, whose corresponding values from the regression analysis were $4.22 \mathrm{mg} / \mathrm{ml}$ $\left(\mathrm{CI}_{50}\right)$ and $8.61 \mathrm{mg} / \mathrm{ml}\left(\mathrm{CI}_{90}\right)$ for leaf extracts, $5.96 \mathrm{mg} /$ $\mathrm{ml}\left(\mathrm{CI}_{50}\right)$ and $11.14 \mathrm{mg} / \mathrm{ml}\left(\mathrm{CI}_{90}\right)$ to stem extracts, and no in vitro cytotoxicity for the $S$. praealtum root extracts (Table 2).

\section{In vivo micronucleus assay}

Given the broad spectrum of antimicrobial action of the lyophilized extract of $S$. praealtum leaves, as noted in this study, only the extracts from leaves have been studied in the in vivo micronucleus assay. Numbers and frequencies of MNPCEs and the PCE/NCE ratio in the mice bone marrow were statistically analyzed for each of the animal groups treated with lyophilized extracts of $S$. praealtum leaves and for each of the groups treated with $150 \mathrm{mM} \mathrm{NaCl}$ and N-Nitroso-N-ethylurea (control groups) - genotoxic assay.

For animal groups treated with extracts of S. praealtum leaves, analysis of MNPCEs showed no significant differences $(p<0.05)$ between treatment doses (500$2000 \mathrm{mg} / \mathrm{kg}$ ) and negative control $(\mathrm{NaCl})$. These results suggest an absence of genotoxicity (no clastogenic and/ or aneugenic effects) of lyophilized hydroalcoholic extract of S. praealtum leaves, regardless of the dose of herbal medicine administration $(500-2000 \mathrm{mg} / \mathrm{kg}$ ) and treatment time ( 24 and $48 \mathrm{~h}$ ), but gender-dependent (male and female). The analysis obtained from the PCE/ NCE ratio showed significant differences $(p<0.05)$ between the control groups $(150 \mathrm{mM} \mathrm{NaCl}$ and $50 \mathrm{mg} / \mathrm{kg}$ of N-Nitroso-N-ethylurea) and all doses of extracts of $S$. praealtum leaves $(500-2000 \mathrm{mg} / \mathrm{kg})$. Therefore, these results suggest that there is a systemic toxicity of the lyophilized hydroalcoholic extract of S. praealtum leaves under $\mathrm{MN}$ assay conditions, regardless of the herbal 
medicine dose and the treatment time ( 24 and $48 \mathrm{~h})$, but gender-dependent (male and female) (Table 3).

\section{Discussion}

Natural products and herbal medicinal plants are a major source of chemical compounds with potential therapeutic applicability [6] and, consequently, these plants can be important healing alternatives. Chemical studies of the Sedum species showed several classes of biologically active substances, such as alkaloids, tannins, flavonoids and cyanogenic compounds [1-4]. In addition, the phytochemical characterization of different Sedum species and the association between chemical compounds and some biological and pharmacological activities and evolutionary events has been demonstrated [1-4, 17] (Table 4). The phytochemical screening of the lyophilized extracts of S. praealtum (stem, leaf and root) by GC-MS reveled the following compounds: leaf of S. praealtum: phytol (relative percentage: $60.92 \%$ ) and propyl pentil phthalate $(30.08 \%)$; stem of $S$. praealtum: sitosterol (24.6\%), ethyl linoleate (18.41\%), ethyl octadecatrienoate (16.81\%), ethyl hexadecanoate $(10.88 \%)$, di octyl phthalate (8.62\%), hexadecanoic acid (5.56\%), phytol (5.06\%), monopalmitin $(4.73 \%)$, hexadecatrienal $(2.95 \%)$ and octadecadienoic acid (2.39\%); and root of S. praealtum: di isoctil phthalate
(65.74\%) and isobutyl undecyl phthalate (11.54\%). Of these compounds, phytol [41], hexadecanoic acid [42, 43] and propyl pentil phthalate [44] were potentially associated with certain biological activities. The phytol exert a wide range of biological effects and it is a potential candidate for a broad range of applications in the pharmaceutical and biotechnological industry. Investigations with phytol demonstrated anxiolytic, metabolism-modulating, cytotoxic, antioxidant, autophagy- and apoptosis-inducing, antinociceptive, antiinflammatory, immune-modulating, and antimicrobial effects [41]. The inhibition of biofilm, extracellular polymeric substances, cell surface hydrophobicity, pyocyanin, pyoveridin and swarming motility of $P$. aeruginosa were observed from the S. platensis methanolic extract (major component identified was hexadecanoic acid) [42]. The significant gastroprotective action, antioxidant (DPPH ${ }^{\circ}, \mathrm{ABTS}^{\circ+}$ and FRAP) and anti-Helicobacter pylori (MIC of $100 \mu \mathrm{g} / \mathrm{ml}$ ) activities were demonstrated from the methanol extract of leaves of $S$. involucrata var. paniculata (C. B. Clarke) Munir (twenty-one compounds identified, among them hexadecanoic acid) [43]. Studies involving both compounds di- $n$-propyl phthalate and di-n-pentyl phthalate (DPP) showed toxicity to the reproductive system (complete inhibition of fertility or reduced fertility towards both male and female mice) associated with

Table 3 The incidence of MNPCEs and PCE/NCE ratio in bone marrow of male ( $\delta$ ) and female (Q) Swiss albinus mice after testing for $24 \mathrm{~h}$ and $48 \mathrm{~h}$. Data are from the controls ( $\mathrm{NaCl}$ and $\mathrm{NEU}$ ) and an evaluation of the genotoxicity of the lyophilized hydroalcoholic extract of S. praealtum leaves

\begin{tabular}{|c|c|c|c|c|c|c|}
\hline \multirow[t]{2}{*}{ Treatment } & \multicolumn{2}{|c|}{ MNPCEs $(n)$} & \multicolumn{2}{|l|}{ MNPCES (\%) } & \multicolumn{2}{|c|}{$\mathrm{PCE} /(\mathrm{PCE}+\mathrm{NCE})$} \\
\hline & $24 h^{A}$ & $48 \mathrm{~h}^{\mathrm{A}}$ & $24 h^{A}$ & $48 \mathrm{~h}^{\mathrm{A}}$ & $24 h^{A}$ & $48 \mathrm{~h}^{\mathrm{A}}$ \\
\hline \multicolumn{7}{|l|}{$150 \mathrm{mM} \mathrm{NaCl}$} \\
\hline o $\mathrm{A}$ (MNPCE); A (PCE/NCE ratio) & $8 \pm 3$ & $7 \pm 3$ & $0.39 \pm 0.09$ & $0.33 \pm 0.16$ & $1.00 \pm 0.00$ & $1.00 \pm 0.00$ \\
\hline$\hat{\sigma}^{\text {B }}$ (MNPCE); B (PCE/NCE ratio) & $8 \pm 3$ & $11 \pm 1$ & $0.37 \pm 0.16$ & $0.53 \pm 0.06$ & $1.00 \pm 0.00$ & $1.00 \pm 0.00$ \\
\hline Mean \pm SD & $8 \pm 3^{A}$ & $9 \pm 3^{A}$ & $0.38 \pm 0.12^{A}$ & $0.43 \pm 0.15^{A}$ & $1.00 \pm 0.00^{\mathrm{A}}$ & $1.00 \pm 0.00^{\mathrm{A}}$ \\
\hline \multicolumn{7}{|c|}{ N-Nitroso-N-ethylurea (NEU: 50 mg/kg) } \\
\hline o $\mathrm{A}$ (MNPCE); A (PCE/NCE ratio) & $27 \pm 9$ & $33 \pm 3$ & $1.33 \pm 0.43$ & $1.63 \pm 0.11$ & $0.54 \pm 0.04$ & $0.75 \pm 0.12$ \\
\hline$\hat{\sigma}^{B}$ (MNPCE); B (PCE/NCE ratio) & $68 \pm 32$ & $35 \pm 5$ & $3.33 \pm 1.54$ & $1.74 \pm 0.27$ & $0.55 \pm 0.10$ & $0.54 \pm 0.11$ \\
\hline Mean \pm SD & $48 \pm 31^{B}$ & $34 \pm 4^{B}$ & $2.33 \pm 1.50^{B}$ & $1.69 \pm 0.20^{B}$ & $0.54 \pm 0.07^{c}$ & $0.65 \pm 0.16^{c}$ \\
\hline \multicolumn{7}{|c|}{ Sedum praealtum A.DC. (500 mg/kg) } \\
\hline o A (MNPCE); A (PCE/NCE ratio) & $9 \pm 7$ & $13 \pm 8$ & $0.44 \pm 0.34$ & $0.60 \pm 0.37$ & $0.90 \pm 0.04$ & $0.92 \pm 0.02$ \\
\hline$\sigma^{\pi}$ B (MNPCE); B (PCE/NCE ratio) & $4 \pm 2$ & $5 \pm 1$ & $0.21 \pm 0.10$ & $0.24 \pm 0.03$ & $0.91 \pm 0.03$ & $0.87 \pm 0.03$ \\
\hline Mean \pm SD & $7 \pm 5^{\mathrm{A}}$ & $9 \pm 7^{\mathrm{A}}$ & $0.33 \pm 0.26^{A}$ & $0.42 \pm 0.31^{\mathrm{A}}$ & $0.90 \pm 0.03^{B}$ & $0.89 \pm 0.03^{B}$ \\
\hline \multicolumn{7}{|c|}{ Sedum praealtum A.DC. (1000 mg/kg) } \\
\hline o A (MNPCE); A (PCE/NCE ratio) & $6 \pm 1$ & $18 \pm 8$ & $0.31 \pm 0.07$ & $0.88 \pm 0.38$ & $0.91 \pm 0.02$ & $0.91 \pm 0.01$ \\
\hline$\hat{\sigma}^{\mathrm{B}}$ (MNPCE); B (PCE/NCE ratio) & $6 \pm 1$ & $13 \pm 1$ & $0.29 \pm 0.07$ & $0.63 \pm 0.05$ & $0.91 \pm 0.02$ & $0.91 \pm 0.02$ \\
\hline Mean \pm SD & $6 \pm 1^{A}$ & $15 \pm 6^{\mathrm{A}}$ & $0.30 \pm 0.07^{\mathrm{A}}$ & $0.76 \pm 0.29^{A}$ & $0.91 \pm 0.02^{B}$ & $0.91 \pm 0.01^{B}$ \\
\hline \multicolumn{7}{|c|}{ Sedum praealtum A.DC. (2000 mg/kg) } \\
\hline q A (MNPCE); A (PCE/NCE ratio) & $9 \pm 4$ & $9 \pm 2$ & $0.46 \pm 0.18$ & $0.44 \pm 0.09$ & $0.92 \pm 0.01$ & $0.91 \pm 0.02$ \\
\hline$\sigma^{B}$ (MNPCE); B (PCE/NCE ratio) & $5 \pm 4$ & $25 \pm 14$ & $0.22 \pm 0.18$ & $1.24 \pm 0.66$ & $0.90 \pm 0.04$ & $0.91 \pm 0.04$ \\
\hline Mean \pm SD & $7 \pm 4^{A}$ & $17 \pm 13^{A}$ & $0.34 \pm 0.21^{A}$ & $0.84 \pm 0.61^{A}$ & $0.91 \pm 0.03^{B}$ & $0.91 \pm 0.03^{B}$ \\
\hline
\end{tabular}


Table 4 Phytochemical characterization studies of Sedum spp. and their associations with biological and pharmacological events, and evolutionary and ecological significance

\begin{tabular}{|c|c|c|}
\hline Species & Phytochemical compound & Biological and pharmacological activity \\
\hline Sedum tatarinowii (root, stem and leaves) [17] & $\begin{array}{l}\text { Total falconoid }(\uparrow m g / g) \text {, Polysaccharide }(\uparrow m g / g) \text {, } \\
\text { Free phenol }(\downarrow \mathrm{mg} / 100 \mathrm{~g}) \text { and Bound phenol } \\
(\downarrow \mathrm{mg} / 100 \mathrm{~g}) \text {. }\end{array}$ & $\begin{array}{l}\text { Antimicrobial test (E. coli, S. aureus, S. } \\
\text { typhimurium and L. monocytogenes). }\end{array}$ \\
\hline Sedum aizoon (root, stem and leaves) [17] & $\begin{array}{l}\text { Total falconoid }(\downarrow \mathrm{mg} / \mathrm{g}) \text {, Polysaccharide }(\downarrow \mathrm{mg} / \mathrm{g}) \text {, } \\
\text { Free phenol }(\uparrow \mathrm{mg} / 100 \mathrm{~g}) \text { and Bound phenol } \\
(\uparrow \mathrm{mg} / 100 \mathrm{~g}) \text {. }\end{array}$ & $\begin{array}{l}\text { Antimicrobial test (E. coli, S. aureus, S. } \\
\text { typhimurium and L. monocytogenes). }\end{array}$ \\
\hline Sedum dendroideum (leaves) [4] & $\begin{array}{l}\text { Flavonoids: kaempferol 3-O-a-rhamnopyranosyl- } \\
(1 \rightarrow 2)-\beta \text {-glucopyranoside-7-O-a } \\
\text { glucopyranoside; kaempferol 3-O-a- } \\
\text { rhamnopyranosyl- }(1 \rightarrow 2)-\beta \text {-glucopyranoside-7-O- } \\
\text { a-rhamnopyranoside; kaempferol 3-O-a- } \\
\text { rhamnopyranoside-7-O-a-rhamnopyranoside } \\
\text { (kaempferitrin); kaempferol 3-O- } \beta \text { - } \\
\text { glucopyranoside-7-O-a-rhamnopyranoside. }\end{array}$ & $\begin{array}{l}\text { In vivo antinociceptive and anti-inflammatory } \\
\text { activities (adult male Swiss mice). }\end{array}$ \\
\hline $\begin{array}{l}\text { Sedum meyeri-johannis Engler, S. bourgaei } \\
\text { Hemsley, S. dendroideum Moç \& Sessé, S. reptans } \\
\text { Clausen, S. acre L., S. brissemoreti Hamet, S. } \\
\text { farinosum Lowe, S. fusiforme Lowe, S. nudum } \\
\text { Aiton, S. anglicum Huds., S. melanantherum DC., } \\
\text { S. alpestre Vill., S. annuum L., S. urvillei DC., S. } \\
\text { litoreum Guss., S. stellatum L., S. album L., S. } \\
\text { brevifolium DC., S. lydium Boiss., S. forsterianum } \\
\text { Sm., S. montanum Song. \& Perr. spp. montanum, } \\
\text { S. rupestre L. ssp. erectum 't Hart and S. sediforme } \\
\text { (Jacq.) Pau. (leaves) [3] }\end{array}$ & $\begin{array}{l}\text { Alkaloids and tannins (proanthocyanidins and } \\
\text { esters of gallic acid) in } 36 \text { species of the } \\
\text { Crassulaceae representing the five largest of } \\
\text { Berger's (1930) six subfamilies, including } 23 \\
\text { Sedum spp. }\end{array}$ & $\begin{array}{l}\text { Characterization of the alkaloids and tannins } \\
\text { (proanthocyanidins and esters of gallic acid) } \\
\text { and their evolutionary and ecological } \\
\text { significance. }\end{array}$ \\
\hline Sedum telephium ssp. maximum (leaves) [2] & $\begin{array}{l}\text { Flavonol glycosides (kaempferol 3-O- } \beta \text { - } \\
\text { neohesperidoside-7-O-a-rhamnoside and } \\
\text { quercetin 3-O- } \beta \text {-neohesperidoside-7-O- }- \text { - } \\
\text { rhamnoside), quercetin, kaempferol and their 3- } \\
\text { giucosides, 7-rhamnosides and 3,7-dirhamnosides }\end{array}$ & To investigate the flavonoids constituents. \\
\hline Sedum cepaea (aerial plant material) [1] & Cyanogenic compound (sarmentosin epoxide) & $\begin{array}{l}\text { Releases HCN after hydrolysis of the oxiran } \\
\text { group to a cyanohydrins. }\end{array}$ \\
\hline
\end{tabular}

decreased body weight, increased liver weight, decreased testis and epididymis weights, decreased epididymal sperm concentration, and elevated seminiferous tubule atrophy [44].

In particular, $S$. praealtum has been used for a long time in traditional medicine as an analgesic and antiinflammatory agent because of its beneficial effect on the treatment of eye pain [10], eye swelling [11], ulcer treatment $[12,13]$, general inflammatory problems $[13$, 14], as contraception [15], anti-fertilization [16] and antinociceptive activity [13]. However, scientific studies on the $S$. praealtum species aiming to understand its antimicrobial, cytotoxic and genotoxic effects have been scarce so far. Therefore, these observations also drove us to evaluate the antimicrobial (gram-negative and grampositive bacteria, yeasts and mycobacteria), cytotoxic (Aedes albopictus cells) and genotoxic potential (clastogenic and/or aneugenic effects) of the lyophilized hydroalcoholic extract $S$. praealtum using in vitro antimicrobial susceptibility and cytotoxicity tests and the in vivo micronucleus assay.
Scientific evidence showed that the organic extracts (solvents of increasing polarity, e.g., ethanolic and ethyl acetate extracts) of medicinal plants have been considered as best solvents for the extraction of antimicrobial substances when compared with aqueous extracts [32, $45,46]$. Our antimicrobial studies, as determined by the agar diffusion method, showed absence of antimicrobial susceptibility (null growth inhibition zone) of gramnegative bacterial strains (E. coli, E. aerogenes, $S$. marcescens, $P$. aeruginosa, $P$. mirabilis and S. typhimurium) against the lyophilized hydroalcoholic extracts of $S$. praealtum stems, leaves and roots. However, grampositive bacterial strains showed susceptibility (zone of inhibition of growth) against the root extract (B. subtilis, $B$. cereus, $M$. luteus and $S$. aureus), followed by the stem (B. cereus, M. luteus and S. aureus) and leaf (B. cereus and $M$. luteus) of $S$. praealtum, with considerable scope of gram-positive bacterial species using root extract, followed by the stem and leaf. In addition, a single smaller growth inhibition zone $(p<0.05)$ was observed on the $M$. luteus specie against the stem extract. The $S$. 
cereviseae yeast showed susceptibility (zone of inhibition of growth) against the stem and root extracts. The $E$. faecalis, C. albicans, M. tuberculosis and M. bovis strains did not show susceptibility to any parts of the $S$. praealtum extract.

Unlike the agar diffusion method, the broth microdilution showed antimicrobial action of lyophilized extracts of $S$. praealtum, its leaves responsible for the greater spectrum of bacterial species and variable values of MIC against gram-negative bacterial species. These results suggested that $(i)$ the lyophilized extracts of $S$. praealtum show gram-negative antibacterial action, showing variable MICs depending on the anatomical part of the plant and the gram-negative bacterial species: leaf $(E$. coli, $S$. marcescens, $P$. aeruginosa, $P$. mirabilis and S. typhimurium: $\mathrm{MIC}=25 \mathrm{mg} / \mathrm{ml} ;$ E. aerogenes: $\mathrm{MIC}=50 \mathrm{mg} / \mathrm{ml})$, stem (E. coli: $\mathrm{MIC}=25 \mathrm{mg} / \mathrm{ml}$ ) and root ( $P$. mirabilis: MIC $=50 \mathrm{mg} / \mathrm{ml}$ ); (ii) the broth microdilution method has increased sensibility to gram-negative antibacterial tests against the plant extracts of $S$. praealtum, when compared with the agar diffusion method; and (iii) bioactive phytochemicals compounds (less polar in nature and/or apolar) of $S$. praealtum with potentially gramnegative antibacterial actions can interact physically and/ or chemically with the conditions of the agar diffusion method and, therefore, generate understated data about the antimicrobial susceptibility profile. To the grampositive bacteria tested, the broth microdilution assay showed antimicrobial action in all lyophilized extracts of $S$. praealtum and variable values of MIC. Thus, these data also reinforce the previous hypothesis about the greater sensitivity of the broth microdilution method, also suggesting that the lyophilized extracts from leaves, stems and roots of $S$. praealtum have gram-positive antibacterial action, showing variable MIC according to the gram-positive bacterial species: leaf (M. luteus: $12.5 \mathrm{mg} /$ $\mathrm{ml}$; B. cereus, E. faecalis and S. aureus: $25 \mathrm{mg} / \mathrm{ml}$; B. subtilis: $50 \mathrm{mg} / \mathrm{ml})$, stem (B. cereus, M. luteus, E. faecalis and S. aureus: $25 \mathrm{mg} / \mathrm{ml}$; B. subtilis: $50 \mathrm{mg} / \mathrm{ml}$ ) and root (B. cereus, M. luteus, E. faecalis and S. aureus: $12.5 \mathrm{mg} /$ $\mathrm{ml}$; B. subtilis: $25 \mathrm{mg} / \mathrm{ml}$ ).

The lyophilized extracts of $S$. praealtum leaves and stems did not show any potential of anti-C. albicans action, as demonstrated by both methods (i.e. agar diffusion and broth microdilution), except for the extract of S. praealtum roots (MIC equal to $25 \mathrm{mg} / \mathrm{ml}$ ). However, antifungal action of all these extracts was observed against the $S$. cerevisiae yeast assay and associated with more favorable MIC results (leaf and root: $6.25 \mathrm{mg} / \mathrm{ml}$; stem: $12.5 \mathrm{mg} / \mathrm{ml}$ ). In this case, the broth microdilution method also showed greater sensibility in determining the antifungal action. No in vitro antimycobacterial action was observed using $S$. praealtum extracts, $M$. tuberculosis and M. bovis strains, and only the agar diffusion method. Bacteriostatic, bactericidal, fungistatic and fungicidal patterns of $S$. praealtum extracts were observed in the susceptible microbial species, and MMCs values were typically above MIC values, and dependent on or independent of the anatomical parts of $S$. praealtum: e.g., S. marcescens (leaf displaying $\mathrm{MMC}^{+}$), P. mirabilis (root displaying $\mathrm{MMC}^{+}$), B. subtilis (root displaying $\mathrm{MMC}^{+}$), M. luteus (leaf, stem and root displaying $\mathrm{MMC}^{+}$), S. aureus (leaf and root displaying $\mathrm{MMC}^{+}$) and $S$. cerevisiae species (leaf, stem and root displaying $\mathrm{MMC}^{+}$).

The absence of correlation between agar diffusion and microdilution methods has been observed in some studies on antimicrobial susceptibility and plant extracts [32, 47]. Although both methods have feasible simplicity and relatively low cost, the microdilution method [48] has showed greater sensitivity to results. Several factors can influence the antimicrobial susceptibility analyses employing various phytochemicals compounds (e.g., culture media, $\mathrm{pH}$, oxygen availability, inoculum and incubation conditions) [49] and, consequently, generate irreproducible results among methods (e.g., microbial growth inhibition zone versus MIC). On the other hand, the methods of extraction of phytochemical compounds (e.g., based on the use of organic solvents, which extract compounds with increasing polarity and better diffusion in agar) and interaction, alteration, depletion or destruction of phytochemical compounds, under test conditions, may reflect on the result of antimicrobial action of plant extracts over the micro-organisms [32, 45, 46]. The conditions of plant cultivation are also prevalent with the influence of biotic and abiotic factors, resulting in limiting effects on the production of bioactive metabolites and influencing the antimicrobial effects (e.g., zone of inhibition, MIC and MMC) [50].

This study showed, for the first time in the literature, data on the antimicrobial action of $S$. praealtum for some strains of gram-negative and gram-positive bacteria, yeasts and mycobacteria. A single comparative study on the amount of some active ingredients of Sedum aizoon and Sedum tatarinowii was conducted to develop and use new sources of plants of Shanxi Huoshan, in China [17]. In this study, the antibacterial assay using the agar diffusion method showed that the polysaccharide extracts of both species of Sedum did not have inhibitory effects against E. coli, S. aureus, S. typhimurium and L. monocytogenes strains. However, the free phenol extracts had significant inhibitory effects on some bacteria: $S$. aizoon (S. aureus, S. typhimurium and L. monocytogenes) and S. tatarinowii (E. coli, S. aureus and L. monocytogenes). Bound phenol or total falconoid extracts of $S$. tatarinowii showed the strongest activity against $L$. monocytogenes (i.e., $\varnothing$ of growth inhibition zone). These results provided a theoretical basis for the 
comprehensive development and utilization of plant resources of Huoshan, in China [17].

In this research, S. praealtum extracts were also tested on Aedes albopictus cells, to determine the percentage of in vitro cytotoxicity $\left(\mathrm{CI}_{50}\right.$ and $\left.\mathrm{CI}_{90}\right)$ and establish a selectivity index $\left(\mathrm{SI}=\mathrm{CI}_{50} / \mathrm{MIC}\right)$. We found a $\mathrm{SI}>1$ in the hydroalcoholic extract of the $S$. praealtum root (absence of in vitro cytotoxicity - IC) against the MICs of the $P$. mirabilis, B. subtilis, B. cereus, M. luteus, E. faecalis, $S$. aureus, C. albicans and S. cerevisiae species. However, such a suggestion could be confirmed from the others in vitro cytotoxicity tests (e.g., human keratinocytes $\mathrm{HaCaT}$ ) and using a higher concentration range (e.g., $\leq 200 \mathrm{mg} / \mathrm{ml}$ and $\geq 5 \mathrm{mg} / \mathrm{ml}$ ). These results suggested the presence of potential cytotoxic phytochemical compounds in S. praealtum leaves and stems, contributing to the $\mathrm{SI}<1$ values. $\mathrm{MIC}$ and $\mathrm{IC}_{50}$ data have been used to calculate the selectivity index (SI) of (phyto)chemical compounds as an estimate of a therapeutic window and a mechanism to identify candidates for effectiveness studies in mice [40]. An SI $\geq 1$ can be considered acceptable [32, 40].

Genotoxicity studies of $S$. praealtum have not been observed in the literature so far, being presented for the first time in this research. The in vivo micronucleus assay was performed with lyophilized extracts of $S$. praealtum leaves, given their broad spectrum of antimicrobial action (gram-negative and gram-positive bacteria and yeast). Data showed no statistically significant differences between the experimental treatments and the negative control of the assay, suggesting the absence of genotoxicity (clastogenic and/or aneugenic) of the hydroalcoholic extract of $S$. praealtum leaves, regardless of herbal medicine doses $(0.5-2 \mathrm{~g} / \mathrm{kg})$ and treatment times ( $24 \mathrm{~h}$ : acute effect; $48 \mathrm{~h}$ : chronic effect), but depending on the sex of the mouse (male and female). The PCE/NCE ratio was analyzed as a measure of toxicity in the bone marrow (systemic toxicity). This PCE/NCE ratio is considered an indicator of accelerating or inhibiting erythropoiesis and has been reported to vary with time. A continuous decline in the PCE/ NCE ratio may be due to the inhibition of cell division, the death of erythroblasts, the removal of damaged cells, or the dilution of the total of existing cells with the newly-formed cells [23, 27]. This analysis revealed statistically significant differences between the control groups of animals ( $150 \mathrm{mM} \mathrm{NaCl} ; 50 \mathrm{mg} / \mathrm{kg} \mathrm{NEU}$ ) and all experimental treatments (i.e., intermediate $\mathrm{PCE} /$ NCE ratio to those of the negative and positive controls). Under in vivo micronucleus assay conditions, these data suggested bone marrow toxicity (i.e., systemic toxicity) promoted by the extract of $S$. praealtum leaves, regardless of herbal medicine doses $(0.5-2 \mathrm{~g} / \mathrm{kg})$ and of treatment times ( 24 and $48 \mathrm{~h}$ ), but genderdependent (male and female mouse).
The results of toxicity in mice bone marrow (systemic toxicity) corroborate with the observations about the in vitro cytotoxicity (Aedes albopictus cells), as well as about the harmful physiological (contraceptive action) $[15,16]$ and cellular modulations (inhibition of sperm motility) [16] previously reported for the S. praealtum species. In addition, the acute toxicity of the lyophilized aqueous extract of the aerial parts of S. praealtum was evaluated in experiments carried out in adult female Wistar rats. In five groups of four rats, the lethality was assessed using death within 7 days as an index of toxicity following PO administration of lyophilized extract (from 500 to $3000 \mathrm{mg} / \mathrm{kg}$ body weight), and no deaths were registered [14]. This toxicological result of $S$. praealtum did not show toxic effects at evaluated doses in comparison with the micronucleus assay (i.e., acute and chronic systemic toxicity), and this could be explained, at least in part, by differences between methods of extraction of phytochemical compounds (i.e., hydroalcoholic versus aqueous).

\section{Conclusions}

This was the first scientific study on the in vivo genotoxic and in vitro antimicrobial and cytotoxic potential of S. praealtum (Balsam). The extract of S. praealtum leaves showed antimicrobial action (static and/or microbicide) of broad spectrum and variable MICs for gramnegative (E. aerogenes, E. coli, P. aeruginosa, P. mirabilis, $S$. marcescens and S. typhimurium), gram-positive (B. cereus, B. subtilis, E. faecalis, $M$. luteus and S. aureus) bacteria and only one yeast species ( $S$. cerevisiae), unacceptable for clinical applications of this nature. Stem $(\mathrm{SI}<1)$ and root $(\mathrm{SI}>1)$ extracts showed more restricted antimicrobial effects (i.e., gram-positive bacteria, E. coli and S. cerevisiae [stem]; gram-positive bacteria, $P$. mirabilis, C. albicans and S. cerevisiae [root]). Although data on in vitro cytotoxicity and root SI under testing conditions were favorable, new assays could confirm its missing toxicity. Antimycobacterial action (M. tuberculosis and $M$. bovis) was not observed. The lyophilized extracts of $S$. praealtum leaves showed non-genotoxic effects (i.e., absence of clastogenic and/or aneugenic mechanisms) and systemic toxicity (i.e., toxicity in mice bone marrow), regardless of herbal medicine doses (0.5$2 \mathrm{~g} / \mathrm{kg}$ ) and treatment times (24 h: acute effect; $48 \mathrm{~h}$ : chronic effect), but gender-dependent (male and female).

Partly, the sum of these results provides a foundation for a comprehensive use and development of plant resources, especially $S$. praealtum. However, the advanced phytochemical characterization together with pharmacological and pharmacogenomics studies (e.g., Salmonella typhimurium test as an indicator of potential carcinogenicity for mammals [Ames test]; gene mutation test in mammalian cells [mouse lymphoma assay]; in vitro 
aneuploidy and cytogenetic tests; in vitro micronucleus test in cultured cells; fluorescent in situ hybridization [FISH] test for mutagenesis; comet test to detect DNA damage and repair in individual cells; functional genomic and proteomic tests for mutagenesis [cDNA microarrays and other array analyses]; DNA nicking assay) of S. praealtum extracts and oils should be conducted to characterize their potential effects and action mechanisms, in addition to establishing limits for human consumption, outlining the potential health risks, and implement rational strategies and chemo-preventive measures.

\section{Abbreviations}

$\mathrm{BHI}$ : Brain heart infusion; CFU: Colony forming units; Cl: Cytotoxicity index; $\mathrm{IC}_{50}$ : Cytotoxicity index of $50 \%$ - concentrations capable of reducing $50 \%$; IC 90 : Cytotoxicity index of $90 \%$ - concentrations capable of reducing $90 \%$; HaCaT: Human keratinocytes; MTD: Maximum tolerated dose;

MTT: Methylthiazolyldiphenyl-tetrazolium bromide; MNPCEs: Micronucleated polychromatic erythrocytes; MIC: Minimum inhibitory concentration; MMC: Minimum microbicide concentration; NEU: N-nitroso-N-ethylurea; NCEs: Normochromatic erythrocytes; PO administration: Oral administration: from "per os", the Latin for "by mouth"; PCEs: Polychromatic erythrocytes; SDA: Sabouraud dextrose agar; SI: Selectivity index

\section{Acknowledgements}

The authors would like to thank Espaço da Escrita (Coordenadoria-geral UNICAMP) for the language services provided.

\section{Authors' contributions}

MFGB, VMP, JFH and DMPS: responsible for the research project, elaboration of the research project, technical work (laboratory), interpretation of the results, genetic analyzes, statistical analyzes, and elaboration/revision of the article. CTSD: statistical analyzes. MBM, TAS, JJS, RAD, THNSF, ILRM, WLCB and NMSO: technical work (laboratory), interpretation of the results and elaboration/revision of the article. All the authors have read and approved the final manuscript prior to submission.

\section{Funding}

This research was supported by Rede Mineira de Ensaios Toxicológicos e Farmacológicos de Produtos Terapêuticos (REDE MINEIRA TOXIFAR), Fundação de Amparo à Pesquisa do Estado de Minas Gerais (FAPEMIG process no. RED-00008-14). These supports were for the design and execution of the experiment.

\section{Availability of data and materials}

The datasets used and/or analysed during the current study are available from the corresponding author on reasonable request.

\section{Ethics approval and consent to participate}

Swiss albinus (Unib: SW) mice were provided by CEMIB (Multidisciplinary Center for Biological Investigation on Laboratory Animal Science UNICAMP). This research was approved by the Ethics Committee in Research Involving Animals of UNIFENAS (CEPEAU Protocol No. 08A/2014).

\section{Consent for publication}

Not applicable.

\section{Competing interests}

The authors declare that they have no competing interests.

\section{Author details}

'Laboratory of Microbiology and Immunology, Department of Oral Diagnosis, Dental School of Piracicaba, State University of Campinas (FOP/UNICAMP), Piracicaba, SP 13414-903, Brazil. ${ }^{2}$ Center for Research and Postgraduate Studies in Animal Science, Pathology and Animal Pharmacology Area, University of Alfenas (UNIFENAS), Alfenas, MG 37132-440, Brazil. ${ }^{3}$ Laboratory of Pharmacogenetics and Molecular Biology, Faculty of Medical Sciences,
University of Alfenas (UNIFENAS), Alfenas, MG 37132-440, Brazil. ${ }^{4}$ Department of Exact Sciences, College of Agriculture, University of São Paulo (ESALQ/ USP), Piracicaba, SP 13418-900, Brazil. ${ }^{5}$ Laboratory of Oral Microbiology and Immunology, Department of Physiology and Oral Pathology, Araraquara School of Dentistry, São Paulo State University (FOAr/UNESP), Araraquara, SP 14801-903, Brazil. ' Reproductive Biology Center, Federal University of Juiz de Fora (UFJF), Juiz de Fora, MG 36036-900, Brazil.

Received: 7 May 2019 Accepted: 7 April 2020

Published online: 29 April 2020

\section{References}

1. Nahrstedt A, Walther A, Wray V. Sarmentosin epoxide, a new cyanogenic compound from Sedum cepaea. Phytochemistry. 1982;21:107-110. https:// doi.org/https://doi.org/10.1016/0031-9422(82)80023-X.

2. Mulinacci $N$, Vincieri FF, Baldi A, Bambagiotti-Alberti M, Sendl A, Wagner $H$. Flavonol glycosides from Sedum telephium subspecies maximum leaves. Phytochemistry. 1995;38:531-533. https://doi.org/https://doi.org/10.1016/ 0031-9422(94)00554-7.

3. Stevens JF, Hart HT, Roeland CHJ, Ham V, Elema ET, Van den Ent MMVX Wildeboer M, Zwaving JH. Distribution of alkaloids and tannins in the Crassulaceae. Biochem Syst Ecol 1995;23(2):157-165. https://doi.org/https:// doi.org/10.1016/0305-1978(95)00082-6.

4. Melo GO, Malvar DC, Vanderlinde FA, Pires PA, Côrtes WS, Filho PG, Muzitano MF, Kaiser CR, Costa SS. Phytochemical and pharmacological study of Sedum dendroideum leaf juice. J Ethnopharmacol 2005:102;217-220. https://doi.org/https://doi.org/10.1016/j.jep.2005.06.015.

5. Clausen RT. Sedum of the trans-Mexican Volcanic Belt: an exposition of taxonomic methods. New York: Cornell University Press; 1959.

6. Rzedowski J, Rzedowski GC. Flora fanerogámica del Valle de México. México: ENCB, IPN e Instituto de Ecología A. C.; 1985.

7. Kerguélen M. Index synonymique de la Flore de France. Paris: Muséum National d'Histoire Naturelle; 1999.

8. Lino PL, Voll CE, Heiffig LS, Aguila JS, Dias CTS, Minami K. Produção de mudas de balsamo (Sedum dendroideum subsp. Praealtum (DC.) R.T. Clausen). Hortic Bras. 2008;26:S4514-7.

9. Lorenzi H, Souza HM. Plantas Ornamentais no Brasil - Arbustivas, Herbáceas e Trepadeiras. São Paulo: Plantarum; 2001.

10. Cruz M. Libellus de medicinalibus indorum herbis: Aztec manuscript (1552). Mexico: Instituto Mexicano del Seguro Social; 1964.

11. Martínez M. Las Plantas Medicinales de México. México: Botas; 1967

12. Carlini EA, Palermo Neto J, Almeida ET, Marigo C. Úlcera por contenção em ratos: ação protetora de extrato aquoso de bálsamo. Estudo Preliminar An Acad Bras Ciênc. 1970:42:267-70.

13. Melo GO, Malvar DC, Vanderlinde FA, Rocha FF, Pires PA, Costa EA, de Matos LG, Kaiser CR, Costa SS. Antinociceptive and anti-inflammatory kaempferol glycosides from Sedum dendroideum. J Ethnopharmacol 2009; 124:228-232. https://doi.org/https://doi.org/10.1016/j.jep.2009.04.024.

14. Meléndez Camargo ME, Buendía Romero M, Ramos Zamora D, Cardona Carrillo P, Villarreal Maldonado ME. Study of the anti-inflammatory effect of Sedum praealtum (Siempreviva) in the rat: dose-dependent response. Proc West Pharmacol Soc. 2002:45:129-30.

15. Silva-Torres R, Montellano-Rosales H, Ramos-Zamora D, Castro-Mussot ME, Cerda-García-Rojas CM. Spermicidal activity of the crude ethanol extract of Sedum praealtum in mice. J Ethnopharmacol. 2003;85:15-7. https:/doi.org/ 10.1016/S0378-8741(02)00335-5.

16. García Pineda J, Wens MA, Valencia A, Gallegos A. Acción de Sedum dendroideum sobre la actividad funcional de los espermatozoides. Archivos de investigación médica. 1986:17:391-7.

17. $\mathrm{Hu} Q P, X u J G$. Active components and antimicrobial activity in two Sedum species grown in Shanxi Huoshan. China J Food Agric Environ. 2012;10:1724. https://doi.org/10.1234/4.2012.2930.

18. Sikkema J, de Bont JA, Poolman B. Mechanisms of membrane toxicity of hydrocarbons. Microbiol Rev. 1995;59:201-22 https://www.ncbi.nlm.nih.gov/ pubmed/7603409.

19. Ames BN. Dietary carcinogens and anticarcinogens. Oxygen radicals and degenerative diseases. Science. 1983;221:1256-1264. https://doi.org/https:// doi.org/10.1126/science.6351251.

20. Purves D, Harvey C, Tweats D, Lumley CE. Genotoxicity testing: current practices and strategies used by the pharmaceutical industry. Mutagenesis. 1995;10:297-312. https://doi.org/https://doi.org/10.1093/mutage/10.4.297. 
21. Varanda EA. Atividade mutagênica de plantas medicinais. Rev Ciênc Farm Básica Apl. 2006;27:1-7.

22. Mateuca R, Lombaert N, Aka PV, Decordier I, Kirsch-Volders M. Chromosomal changes: induction, detection methods and applicability in human biomonitoring. Biochimie. 2006;88:1515-31. https://doi.org/10.1016/j.biochi. 2006.07.004.

23. Organisation for Economic Co-operation and Development. Guideline for the Testing of Chemicals: Mammalian Erythrocyte Micronucleus Test. Paris, Guideline 474; 2016

24. Indart A, Viana M, Clapés S, Izquierdo L, Bonet B. Clastogenic and cytotoxic effects of lipid peroxidation products generated in culinary oils submitted to thermal stress. Food Chem Toxicol 2007:45:1963-1967. https://doi.org/ https://doi.org/10.1016/j.fct.2007.04.019.

25. Chandrasekaran CV, Sundarajan K, Gupta A, Srikanth HS, Edwin J, Agarwal A. Evaluation of the genotoxic potential of standardized extract of Glycyrrhiza glabra (GutGard'M $)$. Regul Toxicol Pharmacol. 2001;61:373-80. https://doi.org/ 10.1016/j.yrtph.2011.10.002.

26. Alves JM, Munari CC, Monteiro Neto MAB, Furtado RA, Senedese JM, Bastos JK, Tavares DC. In vivo protective effect of Copaifera langsdorffii hydroalcoholic extract on micronuclei induction by doxorubicin. J Appl Toxicol. 2013;33:854-60. https://doi.org/10.1002/jat.2777.

27. Boriollo MF, Souza LS, Resende MR, Silva TA, Oliveira NM, Resck MC, Dias CT, Fiorini JE. Nongenotoxic effects and a reduction of the DXR-induced genotoxic effects of Helianthus annuus Linné (sunflower) seeds revealed by micronucleus assays in mouse bone marrow. BMC Complement Altern Med 2014;2:121. https://doi.org/https://doi.org/10.1186/1472-6882-14-121.

28. Porto, RS: Conyza canadensis: determination of bioactive compounds and evaluation of antifungal activity. (2015) http://repositorio.unicamp.br/handle/ REPOSIP/249439. Accessed 18 Dec 2019].

29. CLSI. Method for antifungal disk diffusion susceptibility testing of yeasts: approved guideline—second edition. In: CLSI document M44-A2. Wayne, PA: Clinical and Laboratory Standards Institute; 2009.

30. CLSI. Performance standards for antimicrobial disk susceptibility tests; approved standard —eleventh edition. In: CLSI document M02-A11. Wayne, PA: Clinical and Laboratory Standards Institute; 2012.

31. CLSI. Performance standards for antimicrobial susceptibility tests; twentysecond informational supplement. In: CLSI document M100-S22. Wayne, PA: Clinical and Laboratory Standards Institute; 2012.

32. Silva JJ, Cerdeira CD, Chavasco JM, Cintra AB, Silva CB, Mendonça AN, Ishikawa T, Boriollo MF, Chavasco JK. In vitro screening antibacterial activity of Bidens pilosa Linné and Annona crassiflora Mart. Against oxacillin resistant Staphylococcus aureus (ORSA) from the aerial environment at the dental clinic. Rev Inst Med Trop São Paulo 2014;56:333-340. https://doi.org/https:// doi.org/10.1590/S0036-46652014000400011.

33. CLSI. Reference method for broth dilution antifungal susceptibility testing of yeasts: approved standard —-third edition. In: CLSI document M27-A3. Wayne, PA: Clinical and Laboratory Standards Institute; 2008.

34. CLSI. Methods for dilution antimicrobial susceptibility tests $f$ or Bacteria that grow aerobically; approved standard —ninth edition. In: CLSI document M07-A9. Wayne, PA: Clinical and Laboratory Standards Institute; 2012.

35. CLSI. Reference method for broth dilution antifungal susceptibility testing of yeasts; fourth informational supplement. In: CLSI document M27-S4. Wayne, PA: Clinical and Laboratory Standards Institute; 2012.

36. Martin A, Camacho M, Portaels F, Palomino JC. Resazurin microtiter assay plate testing of Mycobacterium tuberculosis susceptibilities to second-line drugs: rapid, simple, and inexpensive method. Antimicrob Agents Chemother 2003;47:3616-3619. https://doi.org/https://doi.org/10.1128/AAC. 47.11.3616-3619.2003.

37. Cantón E, Pemán J, Viudes A, Quindós G, Gobernado M, Espinel-Ingroff A. Minimum fungicidal concentrations of amphotericin B for bloodstream Candida species. Diagn Microbiol Infect Dis 2003;45:203-206. https://doi.org/ https://doi.org/10.1016/S0732-8893(02)00525-4.

38. Moore CB, Walls CM, Denning DW. In vitro activities of terbinafine against Aspergillus species in comparison with those of itraconazole and amphotericin B. Antimicrob Agents Chemother 2001;45:1882-1885. https:// doi.org/https://doi.org/10.1128/AAC.45.6.1882-1885.2001.

39. CLSI. Susceptibility testing of mycobacteria, Nocardiae, and other aerobic Actinomycetes; approved second-edition. In: CLSI document M24-A2. Wayne, PA: Clinical and Laboratory Standards Institute; 2011.

40. Protopopova M, Hanrahan C, Nikonenko B, Samala R, Chen P, Gearhart J, Einck L, Nacy CA. Identification of a new antitubercular drug candidate,
SQ109, from a combinatorial library of 1,2-ethylenediamines. J Antimicrob Chemother 2005;56:968-974. https://doi.org/https://doi.org/10.1093/jac/ dki319.

41. Islam MT, Ali ES, Uddin SJ, Shaw S, Islam MA, Ahmed MI, Chandra Shill M, Karmakar UK, Yarla NS, Khan IN, Billah MM, Pieczynska MD, Zengin G, Malainer C, Nicoletti F, Gulei D, Berindan-Neagoe I, Apostolov A, Banach M, Yeung AWK, El-Demerdash A, Xiao J, Dey P, Yele S, Jóźwik A, Strzałkowska N, Marchewka J, Rengasamy KRR, Horbańczuk J, Kamal MA, Mubarak MS, Mishra SK, Shilpi JA, Atanasov AG. Phytol: A review of biomedical activities. Food Chem Toxicol. 2018;121:82-94. https://doi.org/https://doi.org/10.1016/ j.fct.2018.08.032

42. LewisOscar F, Nithya C, Alharbi SA, Alharbi NS, Thajuddin N. In vitro and in silico attenuation of quorum sensing mediated pathogenicity in Pseudomonas aeruginosa using Spirulina platensis. Microb Pathog 2018;116: 246-256. https://doi.org/https://doi.org/10.1016/j.micpath.2018.01.046.

43. Sreeja PS, Arunachalam K, Saikumar S, Kasipandi M, Dhivya S, Murugan R, Parimelazhagan T. Gastroprotective effect and mode of action of methanol extract of Sphenodesme involucrata var. paniculata (C.B. Clarke) Munir (Lamiaceae) leaves on experimental gastric ulcer models. Biomed Pharmacother 2018;97:1109-1118. https://doi.org/https://doi.org/10.1016/j. biopha.2017.11.030.

44. Heindel JJ, Gulati DK, Mounce RC, Russell SR, Lamb $4^{\text {th }} \mathrm{JC}$. Reproductive toxicity of three phthalic acid esters in a continuous breeding protocol Fundam Appl Toxicol 1989;12:508-518. https://doi.org/https://doi.org/10. 1016/0272-0590(89)90024-9.

45. Rojas JJ, Ochoa VJ, Ocampo SA, Muñoz JF. Screening for antimicrobial activity of ten medicinal plants used in Colombian folkloric medicine: a possible alternative in the treatment of non-nosocomial infections. BMC Complement Altern Med 2006;17:2. https://doi.org/https://doi.org/10.1186/ 1472-6882-6-2.

46. Mattana CM, Satorres SE, Sosa A, Fusco M, Alcará LE. Antibacterial activity of extracts of acacia aroma against methicillin-resistant and methicillinsensitive Staphylococcus. Braz J Microbiol 2010;41:581-587. https://doi.org/ https://doi.org/10.1590/\$1517-83822010000300007.

47. Chavasco JM, Prado E Feliphe BHM, Cerdeira CD, Leandro FD, Coelho LFL, Silva JJ, Chavasco JK, Dias ALT. Evaluation of antimicrobial and cytotoxic activities of plant extracts from southern Minas Gerais cerrado. Rev Inst Med Trop São Paulo. 2014;56:13-20. http://dx.doi.org/https://doi.org/10.1590/ S0036-46652014000100002.

48. Eloff JN. A sensitive and quick microplate method to determine the minimal inhibitory concentration of plant extracts for bacteria. Planta Med 1998;64:711-713. http://dx.doi.org/https://doi.org/10.1055/s-2006-957563.

49. Ostrosky EA, Mizumoto MK, Lima MEL, Kaneko TM, Nishikawa SO, Freitas BR. Methods for evaluation of the antimicrobial activity and determination of minimum inhibitory concentration (MIC) of plant extracts. Rev Bras Farmacogn 2008;18:301-307. http://dx.doi.org/https://doi.org/10.1590/ S0102-695X2008000200026.

50. Gobbo-Neto L, Lopes NP. Plantas medicinais: fatores de influência no conteúdo de metabólitos secundários. Quím Nova 2007;30:374-381. http:// dx.doi.org/https://doi.org/10.1590/S0100-40422007000200026.

\section{Publisher's Note}

Springer Nature remains neutral with regard to jurisdictional claims in published maps and institutional affiliations.
Ready to submit your research? Choose BMC and benefit from:
- fast, convenient online submission
- thorough peer review by experienced researchers in your field
- rapid publication on acceptance
- support for research data, including large and complex data types
- gold Open Access which fosters wider collaboration and increased citations
- maximum visibility for your research: over $100 \mathrm{M}$ website views per year
At BMC, research is always in progress.
Learn more biomedcentral.com/submissions 